\title{
METHODS TO INCREASE THE RATE OF MASS TRANSFER DURING OSMOTIC DEHYDRATION OF FOODS
}

\author{
Anna Chwastek ${ }^{凶}$ \\ Institute of Chemical Technology of Food, Lodz University of Technology \\ 4/10 Stefanowskiego, 90-924 todź, Poland
}

\begin{abstract}
Traditional methods of food preservation such as freezing, freeze drying (lyophilization), vacuum drying, convection drying are often supplemented by new technologies that enable obtaining of high quality products. Osmotic dehydration is more and more often used during processing of fruits and vegetables. This method allows maintaining good organoleptic and functional properties in the finished product. Obtaining the desired degree of dehydration or saturation of the material with an osmoactive substance often requires elongation of time or use of high temperatures. In recent years much attention was devoted to techniques aimed at increasing the mass transfer between the dehydrated material and the hypertonic solution. The work reviews the literature focused on methods of streamlining the process of osmotic dehydration which include the use of: ultrasound, high hydrostatic pressure, vacuum osmotic dehydration and pulsed electric field.
\end{abstract}

Key words: osmotic dehydration, ultrasound, high hydrostatic pressure, vacuum osmotic dehydration, pulsed electric field

\section{INTRODUCTION}

Seasonality of plant materials causes a drive towards development of an efficient method of their preservation. Nearly all known methods of food preservation involve various transformations, thereby obtaining a product with its quality altered relative to the starting material. Modern alternative food preservation technologies are primarily based on the concept of "minimal processing". Products with high nutritional value and natural sensory characteristics, eliminating the use of preservatives are obtained in this way [Rząca et al. 2009].

Osmotic dehydration aims at extending life of food by removing water without phase transition [Kowalska and Lenart 2001, Matuska et al. 2006]. The process is carried out by immersing the raw material in a hypertonic solution (solution with high concentration of sugars, sodium chloride, sorbitol, glycerol, etc.) [Chenlo et al. 2006, Moreira et al. 2007]. Osmotic dehydration is used for foods with a tissue structure, such as shredded fruit and vegetables [Torreggiani 1993].

The method is based on the natural phenomenon of osmosis through cell membranes of biological material [Shi and Le Maguer 2002]. In the osmotic dehydration the process of water flow to the outside of food material takes place, and entering of substances dissolved in a hypertonic solution into the product. Since the cell membrane is not perfectly selective, the solutes present in cells (organic acids, sugars, minerals, fragrances, and colorants) can pass with water into the hypertonic solution [Derossi et al. 2008].

The osmotic dehydration process does not guarantee full microbiological stability of the product.

凶anna.chwastek@dokt.p.lodz.pl 
Osmotic dehydration leads to lower water activity in the product, between 0.95 and 0.90 and thus it belongs to the class of intermediate moisture foods having the water activity between 0.65 and 0.90 [Yadav and Singh 2012].

Thus the dehydrated material requires further preservation. Osmotic dehydration is treated as a preliminary step prior to freezing [Marani et al. 2007], freezedrying [Garcia-Noguera et al. 2012, Ciurzyńska and Lenart 2010] vacuum drying [Rastogi and Raghavarao 1997], convection drying [Ramaswamy and Nsonzi 1998, Kowalski and Mierzwa 2013]. This technique provides a number of benefits which include limiting of adverse changes in taste, colour, loss of valuable nutrients, inhibition of enzymatic browning, and a great reduction of cost of transport and energy. In the case of convection drying, to evaporate $1 \mathrm{~kg}$ of water $5 \mathrm{MJ}$ of energy is consumed, while in turn, removing $1 \mathrm{~kg}$ of water by osmo-convective drying requires about 0.1-2.4 MJ [Kowalski et al. 2009]. As a result, food preservation by the osmotic-convection method allows for a $20-30 \%$ lower energy consumption when compared with convection drying.

One of the basic pieces of information about the process of osmotic dehydration is the course of its kinetics. The most important process parameters are time, temperature, and the type of the used osmoactive substance [Saurel et al. 1994, Sereno et al. 2001]. Nieto and coworkers [2004] showed that the greatest changes in water content occur during the first 2 hours of osmotic dehydration. Similar results were obtained by Kowalska and Gierada [2005] during osmotic dehydration of apples in a solution of sucrose and apple juice concentrate. The greatest changes in water content were achieved in the initial period of dehydration, up to about 45 minutes.

Along with the increase in temperature the viscosity of the environment decreases, increases the chemical reaction rate, physicochemical changes occur, and thus the processes of osmosis and diffusion intensify. At the same time higher temperature causes a loss of nutrients, changes in the structure, destroying of cell membranes, the loss of selectivity and increase in the amount of osmotic substances penetrating into the interior of the tissue [Nieto et al. 2004]. When carrying out the process according to the high temperature - short time principle, the obtained effect comes not only from dehydration and penetration of osmotic substance, but also from the inactivating impact of the process on enzymes [Lenart 1990].

Osmotic dehydration process using different osmotic substances proceeds differently depending on their molecular weight. Marani et al. [2007] have shown that at the same concentrations the low-molecular substances cause greater penetration of the osmoactive substance inside and a smaller effect of water removal. During osmotic dehydration of kiwi fruit, peach and strawberry, a significantly higher mass gain was observed when using glucose when compared with sugars of a higher molecular weight. Similar conclusions were reached by Pękosławska and Lenart [2009] during osmotic dehydration of pumpkin, where the losses of water from the dehydrated material were higher when glucose solution was used for dewatering than when starch syrup solution was used.

The performed research shows that the type of used osmoactive substance has a significant effect on the sensory qualities of the finished product. Konopac$\mathrm{ka}$ et al. [2009] demonstrated that the use of sucrose, inverted sugar, or deacidified apple concentrate causes a higher evaluation of the sweet taste of dehydrated cherries, blackcurrant and apples than when non-deacidified concentrated fruit juice was used. According to the same authors polyols, such as galactosorbitol (lactose hydrolysate with gal-sorbitol) and sorbitol, are not suitable for osmotic dehydration due to the deterioration of the sensory quality of dehydrated products according to consumer evaluation.

The skin layer of the raw material is a barrier for water and the osmoactive substance [Lewicki and Lenart 2006]. To shorten the time of osmotic dehydration and avoid the use of high temperatures in recent years new development trends are seen, including measures aiming at acceleration of mass transfer during osmotic dehydration. This work is a review of literature on modern methods of pre-treatment before osmotic dehydration, allowing to increase the permeability of the skin layer of the material. The most popular pretreatment methods include non-thermal treatments that improve the mass transfer conditions and do not cause adverse changes in the product such as colour change or irreversible degradation of biologically active compounds. These include: the use of ultrasound, high 
hydrostatic pressure, vacuum osmotic dehydration and pulsed electric field [Rastogi et al. 2002, Knorr 2003].

\section{ULTRASOUND}

Ultrasonic techniques have long been used in the food industry both in food analysis and in food processing and preservation. One can also use them in order to increase the level of safety of food products. In food technology primarily utilized is the ability of ultrasonic waves with high power and low frequency (20-100 kHz) to induce a cavitation effect, which affects the physicochemical and biochemical properties of the material, in particular the disintegration of the cell structures [Kapturowska et al. 2011, Dolatowski et al. 2007]. The action of acoustic waves (ultrasound) on plant tissue causes a number of contractions, leading to the removal of water and gives an effect similar to "squeezing" of a sponge. This procedure contributes to the formation of microscopic canals and improves the capillary flow of osmotic solution to the intercellular spaces of the dewatered material [Deng and Zhao 2008]. In recent years, many studies have been presented, using the sonication effect for osmotic dehydration as an alternative enabling the execution of the process at lower temperatures [Fernandes and Rodrigues 2007].

Nowacka et al. [2014] confirmed in their study that the initial exposure of the kiwi fruit to ultrasound of frequency of $35 \mathrm{kHz}$ for 30 min causes a mass gain of $45 \%$ compared to trials not subject to sonication process. The authors observed a clear change in the structure of tissues, which was associated with an increase in the average cross-sectional area. Simal et al. [1998] carried out osmotic dehydration of apples in $70^{\circ}$ Brix sucrose solution at $40,50,60$ and $70^{\circ} \mathrm{C}$, supporting the process with ultrasounds of $50 \mathrm{kHz}$ frequency. The obtained results confirmed the significant impact of sonication on the level of penetration of osmoactive substance into the fruit. The gain in dry matter ranged from $23 \%$ at $40^{\circ} \mathrm{C}$ to $11 \%$ in $70^{\circ} \mathrm{C}$ after $3 \mathrm{~h}$ of dehydration. Water loss from the material increased by $14-27 \%$ compared to control, regardless of the temperature. Xin et al. [2013] have shown that the use of ultrasound allows to shorten the time of osmotic dehydration of broccoli from 120 to 30 minutes. Additionally, ultrasound-assisted osmotic dehydration minimizes the loss of L-ascorbic acid (retention: $79.7-84.4 \%$ compared to $63.4-72.3 \%$ in undehydrated frozen broccoli samples) and improved colour retention and firmness during refrigerated storage at $-25^{\circ} \mathrm{C}$ for 6 months.

Osmotic dehydration is a process that allows to introduce into the dewatered material bioactive ingredients (e.g. vitamins) or texture forming compounds, which enter into the tissue along with the components of a hypertonic solution. Bellary et al. [2011] conducted studies on the assessment of possibility of saturation of coconut slices with curcuminoids during osmotic dehydration assisted with acoustic waves of a frequency of $35 \mathrm{kHz}$. HPLC analysis confirmed that all of curcuminoids migrated from the hypertonic solution into the dewatered material. The authors found that the application of ultrasound caused an improvement of dry mass gain, loss of water, and the amount of bioactive compounds introduced with the hypertonic solution.

Numerous works are devoted to studies of the impact of ultrasound before osmo-convection drying. Oliveira et al. [2011] conducted a drying of Malay apples, which were initially dehydrated in $25^{\circ}$ Brix sucrose solution using ultrasound at a frequency of $25 \mathrm{kHz}$. It has been found that the use of sonification helped to shorten the drying time by $28.1 \%$ compared to the sample dehydrated without the use of acoustic waves.

It has been reported that an important issue is the appropriate choice of parameters of ultrasonic treatment. During sonication thermal energy is released, which could cause local heating of the tissue, which is associated with the effect of cavitation which may depend on the used sequence, time, power, and frequency of pulses [Nowacka et al. 2014].

Shamaei et al. [2011] compared the effect of ultrasound of low $(35 \mathrm{kHz})$ and high frequency $(130 \mathrm{kHz})$ during osmotic dehydration of cranberries. The results showed that the use of acoustic waves with a lower intensity is more preferable from the viewpoint of maintaining the firmness and colour of skin of the dewatered material. The use of higher frequency ultrasound caused numerous cracks and damage to the structure, while the use of more gentle conditions resulted in the formation of a low number of microchannels.

Research conducted by Kek et al. [2013] aimed at comparing of ways of conducting of ultrasonic 
treatment during osmotic dehydration of guway. In a first embodiment the ultrasonic wave generating probe was immersed directly into the solution with the material, in the second the dehydrated sample placed in a plastic container was immersed in an ultrasonic bath. Indirect sonication with the ultrasonic bath at $1.75 \mathrm{~kW}$ and $60 \mathrm{~min}$ of immersion time in $70^{\circ}$ Brix osmotic solution contributed to the highest water loss of $0.34 \mathrm{~g}$ water $/ \mathrm{g}$, solid gain of $0.089 \mathrm{~g}$ solid $/ \mathrm{g}$, and acceptable change of total colour. When ultrasound was used as pre-treatment in osmotic solutions for a hot-air drying process, it decreased the drying time by $17-33 \%$.

\section{High Hydrostatic Pressure (HHP)}

High Pressure Processing (abbreviated HHP) is applied on an industrial scale in many countries mainly in order to extend the shelf life of food as a result of reducing the number of microorganisms or enzyme activity. It can also be used to modify the functional properties of individual components of the raw material and the finished product, thereby creating new rheological, primarily textual properties [Pietrzak 2010]. According to literature, subjecting of food subjected to the initial impact of a high hydrostatic pressure causes cell disruption. The indicator of cell disintegration after treatment of the material with a high pressure increases with time. Most often, the pressure in the

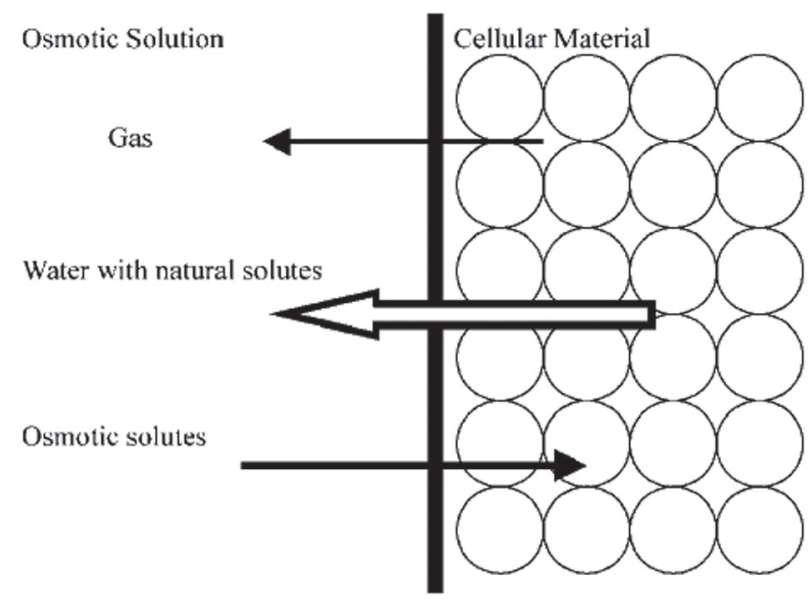

Fig. 1. Mass transfer pattern when a cellular material is immersed in osmotic solution [Shi and Le Maguer 2002] range of 100 to $800 \mathrm{MPa}$ is used, causing a permabilization of the cellular structure. This phenomenon can be used to enhance mass transfer during osmotic dehydration [Rastogi et al. 1994, Nuñez-Mancilla et al. 2011]. Verma et al. [2014] showed that pretreatment of the material using high pressure technology allows for acceleration of mass transfer during osmotic dehydration of banana slices. Under pressure occurs a breaking of the cell membrane integrity, making cells more permeable. A confirmation of the authors' hypothesis were pictures taken using a scanning electron microscope. Similar conclusions were reached by Taiwo et al. [2003 a] for osmotic dehydrating of strawberry fruit pretreated with a pressure of $200 \mathrm{MPa}$ for $5 \mathrm{~min}$, the water loss in the samples under vacuum for $2 \mathrm{~h}$ was $8-73 \%$ greater than for those at atmospheric pressure for $4 \mathrm{~h}$.

An important issue from a methodological point of view is the appropriate selection of conditions of material processing using high pressure technology. Rastogi and Niranjan [1998] confirmed the significant influence of different pressures on the kinetics of osmotic dehydration of pineapple (Fig. 2). It has been found that the use of higher pressures resulted in increased mass gains and losses of water in the material. Using a pressure of $700 \mathrm{MPa}$, a mass gain of pineapple dehydrated for 180 minutes was approximately $30 \%$ greater in relation to dehydration at $100 \mathrm{MPa}$. In other research Rastogi et al. [2000] have shown that the use of higher osmotic pressure during the dehydration of pineapple results in higher permabilization of cells. The $\mathrm{Zp}$ (cell disintegration index) values of the untreated sample did not change with time and remained zero. The $\mathrm{Zp}$ values of the center layer after $5 \mathrm{~h}$, for the control and sample treated at $200 \mathrm{MPa}$ were 0.18 and 0.28 , respectively. In case of samples treated at 400 $\mathrm{MPa}$, the $\mathrm{Zp}$ values were 0.82 .

Sopanangkul et al. [2002] performed osmotic dehydration of potato cylinders; the material was earlier prepared for dehydration using different pressure conditions (200 to $500 \mathrm{MPa}$ ). Studies have shown that the use of pressures above $400 \mathrm{MPa}$ leads to gelation of starch and thus hinders diffusion of water and osmoactive substance. Literature data shows that osmotic dehydration conducted under conditions of elevated pressure may affect the nutrient content and quality of the dehydrated material. Nuñez-Mancilla et al. [2014] 

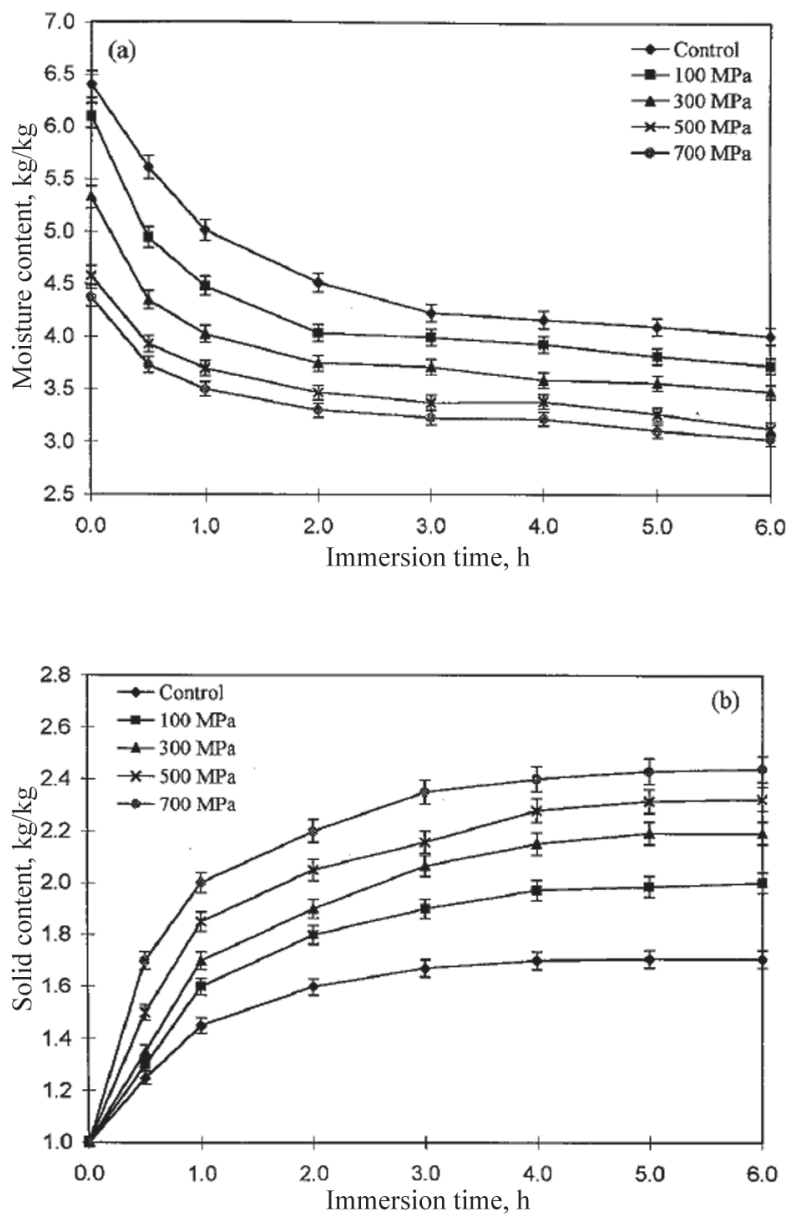

Fig. 2. Moisture and solid content with time during osmotic dehydration of pineapple [Rastogi and Niranjan 1998]

conducted osmotic dehydration of strawberries under a pressure of 100-500 MPa for $10 \mathrm{~min}$. The highest total polyphenols retention was found when using 100 $\mathrm{MPa}(78 \%$ and $96 \%$, respectively). At higher pressure (200-500 MPa) total polyphenols retention was lower (from $93 \%$ to $72 \%$ ). The content of flavonoids in fruits was similar when 200-400 MPa were applied (retention from 77 to $64 \%$ ).

In other studies, Nuñez-Mancilla et al. [2013] showed that the negative effect of high pressure may be acceleration of non-enzymatic browning reactions. The pressures 300, 400 and $500 \mathrm{MPa}$ present the highest browning when compared to 200 and $300 \mathrm{MPa}$ during osmotic dehydration of strawberries.

\section{Pulsed Vacuum Osmotic Dehydration (PVOD)}

Vacuum impregnation is becoming widely used in the food industry. Most commonly it is used for materials of animal origin and fruits. This method is considered to be a useful technique for the rapid introduction of external fluids into the porous structure of plant and animal tissues in a controlled manner [Fito and Chiralt 1994].

In literature there are numerous reports on the application of negative pressure during osmotic dehydration. The use of a VOD (vacuum osmotic dehydration) initial process for different periods of time, followed by the application of OD (osmotic dehydration) is called a pulsed vacuum osmotic dehydration (PVOD) process [Tapia et al. 1999]. PVOD has been reported the osmotic dehydration of apples [Paes et al. 2007, Moreno et al. 2011] pineapples [Lombard et al. 2008], guavas [Panades et al. 2008, Pino et al. 2008], mangoes [Giraldo et al. 2003]. Vacuum is applied during short periods of time that last from 10 to $20 \mathrm{~min}$ and then is released, giving place to PVOD-OD cycles, which, in conjunction with osmotic gradients, produce compression and relaxation of the viscoelastic food matrix, thus favoring OD [Santacruz-Vazquez et al. 2008]. According to literature negative pressure leads to the release of the internal gas or liquid trapped in the pores to the surrounding solution, which is the effect of operation of hydrostatic mechanisms [Mujica-Paz et al. 2003 a].

The most important advantage of PVOD is the acceleration of mass exchange and shortening the OD time. In order to develop conditions for PVOD one must take into account the following process parameters: the level of pressure and time of its action, the type and concentration of the used osmotic agent, the porosity and the geometrical shape of the sample [Chafer et al. 2003, Corrêa et al. 2010].

Ferrari et al. [2011] studied the vacuum dehydration (0.01 MPa, 40, 50, $60^{\circ}$ Brix sucrose solutions) of melon cubes. The use of lower-viscosity solutions combined with the action of vacuum pulse at the beginning of process promoted greater solid uptake, which decreased as solution concentration increased. Escriche et al. [2000] in their experiments showed that PVOD (50 mbar, time $15 \mathrm{~min}$ ) of kiwifruit with concentrated grape juice $\left(63^{\circ} \mathrm{Brix}\right)$ led to an increase of the diffusion coefficient by $20 \%$ when compared with $65^{\circ}$ Brix sucrose solution used under the same condition. 
Viana et al. [2013] confirmed that the structure of the material is of vital importance during the POVD. The method has proven to be ineffective in the case of fodder palm, which is not a porous structure and the texture is quite hard.

Bórquez et al. [2010] showed that in osmotic dewatering of raspberry fruit using a pressure of $1.33 \mathrm{MPa}$ for a period of $8 \mathrm{~min}$ the water loss was approximately 3-4 times higher than the massgain. By impregnation with a solution of sucrose the mechanical resistance, color and flavor of fruits have been improved. MujicaPaz et al. [2003 b] studied the effect of different pressure conditions on the water content in the material. They found that the higher the vacuum, the lower the volume of liquid in the sample. Applying a pressure below $0.04 \mathrm{MPa}$ removed practically all of the aqueous phase from the pores of the tissue structure.

Matusek et al. [2008] showed that a 5 min treatment of apples with oligofructose (oligofructose content: $93.2 \%$ glucose + fructose - sucrose $6.8 \%$ ) at a pressure of 700 mbar results in a reduction of moisture by approximately $12 \%$ when compared to samples dehydrated without pressure. The results of treatment of the material with vacuum led to a higher fructo-oligosaccharide impregnation level.

Use of PVOD improved the ability to introduce beta-caroten into apple slices using a solution of sucrose. The PVOD treated samples ( $0.013 \mathrm{MPa}$ during $10 \mathrm{~min}$, followed by a 50-minute relaxation period at atmospheric pressure) shown an increase of this compound by $6 \mathrm{mg} \beta$-carotene/g dry solids after $50 \mathrm{~min}$ utes of dehydration while in samples osmotically dehydrated for 10 it was up to $4.16 \mathrm{mg} \beta$-carotene/g dry solids [Santacruz-Vazquez et al. 2008].

\section{Pulsed Electric Field (PEF)}

The essence of the use of electric waves of high voltage amplitude is the plasmolysis induced by the electric field (electroplasmolysis). Currently, the most popular and widely accepted explanation for this phenomenon is the electroporation of cell membrane, meaning the formation or growth of the native, existing membrane pores. The destruction of the natural structure of cell membrane (perforation) facilitates the process of diffusion of water and compounds dissolved in it. This reduces the mass flow resistance and causes the acceleration of osmotic dehydration [Wiktor and Witrowa-Rajchert 2012].
Wiktor et al. [2014] showed that the use of PEF for pretreatment before osmotic dehydration of apples results in increased losses of water compared to control. In these studies, in the case of penetration of osmoactive substance the method has not been effective. The most optimum conditions were the cases of PEF treatment of the material as a function of the electric field intensity up to $5 \mathrm{kV} / \mathrm{cm}$ and 10 pulses. Amami and Vorobiev [2005] confirmed that water loss and penetration of the osmoactive substance during osmotic dehydration of apples increases with increasing electric field strength and the number of pulses. When the number of pulses was varied from 100 (energy input: $2.3 \mathrm{~kJ} / \mathrm{kg}$ ) to 750 (energy input: $13.5 \mathrm{~kJ} / \mathrm{kg}$ ). Evaluation of the impact of the pretreatment using electric waves of high voltage amplitude was made by Amami et al. [2007] during the osmotic dehydration of carrots. This method helped to increase the mass transfer. Water loss from the dehydrated material increased by up to $42 \%$ after 2 hours compared to samples not treated with the electric field.

Ade-Omowaye et al. [2003 a] observed an increase in the conductivity of dehydrated tissue of red peppers. The greatest changes were observed in the high frequency range. The authors explain the phenomenon through the cell membrane acting as an electrical insulator, and that the current flow was mainly confined to extracellular fluid in low frequencies. The use of PEF increased the water loss by $11-25 \%$ and mass gain by $2-5 \%$. In another experiment, Ade-Omowaye et al. [2003 b] have demonstrated that the retention of vitamin $\mathrm{C}$ during osmotic dehydration of red peppers was dependent on the number of applied pulses. The highest retention was the characteristics of samples subjected to 1 pulse and the lowest were the ones subjected to 20 pulses (retention amounted to 89.6 to $96.5 \%$ respectively). Taiwo et al. [2003 b] observed that the use of higher field strengths caused a drop in the amount of vitamin $\mathrm{C}$ during osmotic dehydration of apples. The vitamin $\mathrm{C}$ content in the samples treated with $2 \mathrm{kV} / \mathrm{cm}$ was from 50 to $60 \%$ lower than for samples treated with 0.5 and $1.0 \mathrm{kV} / \mathrm{cm}$. Amami et al. [2008] determined the effect of preliminary, PEF-assisted osmotic dehydration $(\mathrm{E}=0.6 \mathrm{kV} / \mathrm{cm})$ on the course of convective drying of carrots. They found that PEF pretreatment shortened the drying time $\left(60^{\circ} \mathrm{C}\right)$ to a moisture content of $0.1 \mathrm{~g} / \mathrm{g} \mathrm{dw}$ by about $20 \%$, and 
the pulsed electric field assisted osmotic dehydration reduced the drying time from 290 to 70 minutes. Exposure time of the material to high temperature, thanks to the combined pretreatment shortened by as much as $81 \%$ compared with the material subjected to no pretreatment [Wiktor and Witrowa-Rajchert 2012].

\section{SUMMARY}

The use of high hydrostatic pressure, pulsed electric field of high voltage, ultrasound has a considerable application potential; is a very good alternative to thermal methods.

Literature review presented in this paper confirms that the mentioned methods of preliminary preparation of fruit for osmotic dehydration have a significant effect on the kinetics of the process. The presented treatments accelerate the rate of penetration of osmoactive substances, as well as the removal of water from the dehydrated material, which can shorten the time of osmotic dehydration. Through the damage of the skin layer of fruit and vegetables it is made possible to introduce bioactive (e.g. vitamins) or texture forming components into the raw material together with the solution, which would enter into the tissue together with the components of a hypertonic solution. However, the knowledge contained in the available literature points to the desirability of optimization and selection of relevant parameters of the used processes individually to each dehydrated material.

\section{REFERENCES}

Ade-Omowaye B.I.O., Talens P., Angersbach A., Knorr D., 2003 a. Kinetics of osmotic dehydration of red bell peppers as influenced by pulsed electric field pretreatment. Food Res. Int. 36(5), 475-483.

Ade-Omowaye B.I.O., Taiwo K.A., Eshtiaghi N.M., Angersbach A., Knorr D., 2003 b. Comparative evaluation of the effects of pulsed electric field and freezing on cell membrane permeabilisation and mass transfer during dehydration of red bell peppers. Innovat. Food Sci. Emerg. Techn. 4(2), 177-188.

Amami E., Vorobiev E., 2005. Effect of pulsed electric field on the osmotic dehydration and mass transfer kinetics of apple tissue. Drying Techn. 23(3), 581-595.

Amami E., Fersi A., Vorobiev E., Kechaou N., 2007. Osmotic dehydration of carrot tissue enhanced by pulsed electric field, salt and centrifugal force. J. Food Eng. 83(4), 605-613.

Amami E., Khezami L., Vorobiev E., Kechaou N., 2008. Effect of pulsed electric field and osmotic dehydration pretreatment on the convective drying of carrot tissue. Drying Techn. 26, 231-238.

Bellary A.N., Sowbhagya H.B., Rastogi N.K., 2011. Osmotic dehydration assisted impregnation of curcuminoids in coconut slices. J. Food Eng. 105(3), 453-459.

Bórquez R.M., Canales E.R., Redon J.P., 2010. Osmotic dehydration of raspberries with vacuum pretreatment followed by microwave-vacuum drying. J. Food Eng. 99(2), 121-127.

Chafer M., Gonzalez-Martinez C., Fernandez B., Perez L., Chiralt A., 2003. Effect of blanching and vacuum pulse application on osmotic dehydration of pear. Food Sci. Technol. Int. 9(5), 321-328.

Chenlo F., Chaguri L., Santos F., Moreira R., 2006. Osmotic dehydration/impregnation kinetics of padrón pepper (Capsicum annuum L. Longum) with sodium chloride solutions: process modelling and colour analysis. Food Sci. Technol. Int. 12(3), 221-227.

Ciurzyńska A., Lenart A., 2010. Structural impact of osmotically pretreated freeze-dried strawberries on their mechanical properties. Int. J. Food Prop. 13(5), 1134-1149.

Corrêa J.L., Pereira L.M., Vieira G.S., Hubinger M.D., 2010. Mass transfer kinetics of pulsed vacuum osmotic dehydration of guavas. J. Food Eng. 96(4), 498-504.

Deng Y., Zhao Y., 2008. Effect of pulsed vacuum and ultrasound osmopretreatments on glass transition temperature, texture, microstructure and calcium penetration of dried apples (Fuji). LWT - Food Sci. Technol. 41(9), 1575-1585.

Derossi A., De Pilli T., Severini C., McCarthy M.J., 2008. Mass transfer during osmotic dehydration of apples. J. Food Eng. 86, 519-528.

Dolatowski Z.J., Stadnik J., Stasiak D., 2007. Applications of ultrasound in food technology. Acta Sci. Pol. Technol. Aliment. 6 (3), 89-99.

Escriche I., Garcia-Pinchi R., Andres, A., Fito P., 2000. Osmotic dehydration of kiwifruit (Actinidia chinensis): fluxes and mass transfer kinetics. J. Food Process Eng. 23(3), 191-205.

Fernandes A.N., Rodrigues S., 2007. Ultrasound as pretreatment for drying of fruits: dehydration of banana. J. Food Eng. 82, 261-267.

Ferrari C.C., Arballo J.R., Mascheroni R.H., Hubinger M.D., 2011. Modelling of mass transfer and texture evaluation during osmotic dehydration of melon under vacuum. Int. J. Food Sci. Technol. 46(2), 436-443. 
Fito P., 1994. Modelling of vacuum osmotic dehydration of food. J. Food Eng. 22, 313-328.

Garcia-Noguera J., Oliveira F.I., Weller C.L., Rodrigues S., Fernandes F.A., 2012. Effect of ultrasonic and osmotic dehydration pre-treatments on the colour of freeze dried strawberries. J. Food Sci. Technol. DOI 10.1007/ s13197-012-0724-x.

Giraldo G., Talens P., Fito P., Chiralt A., 2003. Influence of sucrose solution concentration on kinetics and yield during osmotic dehydration of mango. J. Food Eng. 58(1), 33-43.

Kapturowska A., Stolarzewicz I., Chmielewska I., Białecka-Florjańczyk E., 2011. Ultradźwięki - narzędzie do inaktywacji komórek drożdży oraz izolacji białek wewnątrzkomórkowych [Ultrasounds - a tool to inactivate yeast and to extract intracellular protein]. Żywn. Nauka. Technol. Jakość 4 (77), 160-171 [in Polish].

Kek S.P., Chin N.L., Yusof Y.A., 2013. Direct and indirect power ultrasound assisted pre-osmotic treatments in convective drying of guava slices. Food Bioprod. Process. 91(4), 495-506.

Kowalska H., Lenart A., 2001. Mass exchange during osmotic pretreatment of vegetables. J. Food Eng. 49(2), 137-140.

Kowalska H., Gierada K., 2005. Nasycanie jabłek w celu otrzymania żywności wzbogaconej witaminą C [Impregnation of the apples in order to getting food enriched with vitamin C]. Inż. Roln. 71(11), 267-272 [in Polish].

Kowalski S.J., Mierzwa D., Śronek B., 2009. Drying of osmotically dehydrated biological materials. Chem. Process Eng. 30, 559-568.

Kowalski S.J., Mierzwa D., 2013. Influence of osmotic pretreatment on kinetics of convective drying and quality of apples. Drying Techn. 31(15), 1849-1855.

Konopacka D., Jesionkowska K., Klewicki R., Bonazzi C., 2009. The effect of different osmotic agents on the sensory perception of osmo-treated dried fruit. J. Hortic. Sci. Biotechnol. 1, 80.

Knorr D., 2003. Impact of non-thermal processing on plant metabolites. J. Food Eng. 56(2), 131-134.

Lenart A., 1990. Osmotyczne odwadnianie jako obróbka wstępna przed suszeniem konwekcyjnym owoców i warzyw [Osmotic dehydration as a pretreatment of fruits and vegetables before convective dryling]. Przem. Spoż. 12, 307-309.

Lewicki P.P., Lenart A., 2006. Osmotic dehydration of fruits and vegetables. In: Handbook of industrial drying-3. Ed. A.S. Mujumdar. Taylor and Francis, 665-688.

Lombard G.E., Oliveira J.C., Fito P., Andrés A., 2008. Osmotic dehydration of pineapple as a pre-treatment for further drying. J. Food Eng. 85(2), 277-284.
Marani C.M., Agnelli M.E., Mascheroni R.H., 2007. Osmo-frozen fruits: mass transfer and quality evaluation. J. Food Eng. 79(4), 1122-1130.

Matusek A., Czukor B., Merész P., Örsi F., 2008. Comparison of diffusion of fructo-oligosaccharide components during vacuum impregnation and osmotic dehydration. Eur. Food Res. Technol. 227(2), 417-423.

Matuska M., Lenart A., Lazarides H.N., 2006. On the use of edible coatings to monitor osmotic dehydration kinetics for minimal solids uptake. J. Food Eng. 72(1), 85-91.

Moreira R., Chenlo F., Torres M.D., Vázquez G., 2007. Effect of stirring in the osmotic dehydration of chestnut using glycerol solutions. LWT - Food Sci. Technol. 40(9), 1507-1514.

Moreno J., Simpson R., Estrada D., Lorenzen S., Moraga D., Almonacid S., 2011. Effect of pulsed-vacuum and ohmic heating on the osmodehydration kinetics, physical properties and microstructure of apples (cv. Granny Smith). Innovat. Food Sci. Emerg. Technol. 12(4), 562-568.

Mujica-Paz H., Valdez-Fragoso A., Lopez-Malo A., Palou E., Welti-Chanes J., 2003 a. Impregnation properties of some fruits at vacuum pressure. J. Food Eng. 56, 307-314.

Mujica-Paz A., Valdez-Fragoso A., Lopez-Malo A., Palou E., Welti-Chanes J., 2003 b. Impregnation and osmotic dehydration of some fruits: effect of the vacuum pressure and syrup concentration. J. Food Eng. 57(4), 305-314.

Nieto A.B., Salvatori D.M., Castro M.A., Alzamora S.M., 2004. Structural changes in apple tissue during glucose and sucrose osmotic dehydration: shrinkage, porosity, density and microscopic features. J. Food Eng. 61, 2, 269-278.

Nowacka M., Tylewicz U., Laghi L., Dalla Rosa M., Witrowa-Rajchert D., 2014. Effect of ultrasound treatment on the water state in kiwifruit during osmotic dehydration. Food Chem. 144, 18-25.

Nuñez-Mancilla Y., Perez-Won M., Vega-Gálvez A., Arias V., Tabilo-Munizaga G., Briones-Labarca V., Di Scala K., 2011. Modeling mass transfer during osmotic dehydration of strawberries under high hydrostatic pressure conditions. Innovat. Food Sci. Emerg. Technol. 12(3), 338-343.

Nuñez-Mancilla Y., Pérez-Won M., Uribe E., Vega-Gálvez A., Di Scala K., 2013. Osmotic dehydration under high hydrostatic pressure: effects on antioxidant activity, total phenolics compounds, vitamin $\mathrm{C}$ and colour of strawberry (Fragaria vesca). LWT - Food Sci. Technol. 52(2), 151-156. 
Núñez-Mancilla Y., Vega-Gálvez A., Pérez-Won M., Zura L., García-Segovia P., Di Scala K., 2014. Effect of osmotic dehydration under high hydrostatic pressure on microstructure, functional properties and bioactive compounds of strawberry (Fragaria Vesca). Food Bioprocess Technol. 7(2), 516-524.

Oliveira F.I., Gallão M.I., Rodrigues S., Fernandes A.N., 2011. Dehydration of malay apple (Syzygium malaccense L.) using ultrasound as pre-treatment. Food Bioprocess Technol. 4(4), 610-615.

Paes S.S., Stringari G.B., Laurindo J.B., 2007. Effect of vacuum and relaxation periods and solution concentration on the osmotic dehydration of apples. Int. J. Food Sci. Technol. 42(4), 441-447.

Panades G., Castro D., Chiralt A., Fito P., Nuñez M., Jimenez R., 2008. Mass transfer mechanisms occurring in osmotic dehydration of guava. J. Food Eng. 87(3), 386-390.

Pękosławska A., Lenart A., 2009. Wpływ rodzaju i stężenia substancji osmotycznej na przebieg odwadniania osmotycznego dyni [Effect of kind and concentration of osmotic solution on the kinetics of osmotic dehydration of pumpkin]. Żywn. Nauka Technol. Jakość 1 (62), 119-127 [in Polish].

Pietrzak D., 2010. Perspektywy stosowania wysokich ciśnień w produkcji żywności wygodnej z mięsa drobiowego [Prospects for using high pressure technologies in manufacturing convenience food from poultry meat]. Żywn. Nauka Technol. Jakość 2(69), 16-28.

Pino J.A., Panades G., Fito P., Chiralt A., Ortega A., 2008. Influence of osmotic dehydration on the volatile profile of guava fruits. J. Food Qual. 31(3), 281-294.

Ramaswamy H.S., Nsonzi F., 1998. Convective-air drying kinetics of osmotically pre-treated blueberries. Drying Technol. 16(3-5), 743-759.

Rastogi N.K., Angersbach A., Knorr D., 2000. Synergistic effect of high hydrostatic pressure pretreatment and osmotic stress on mass transfer during osmotic dehydration. J. Food Eng. 45(1), 25-31.

Rastogi N.K., Niranjan K., 1998. Enhanced mass transfer during osmotic dehydration of high pressure treated pineapple. J. Food Sci. 63 (3), 508-511.

Rastogi N.K., Raghavarao K.S.M.S., 1997. Water and solute diffusion coefficients of carrot as a function of temperature and concentration during osmotic dehydration. J. Food Eng. 34(4), 429-440.

Rastogi N.K., Subramanian R., Raghavarao K.S.M.S., 1994. Application of high pressure technology in food industry. Indian Food Ind. 13, 30-34.
Rastogi N.K., Raghavarao K.S.M.S., Niranjan K., Knorr D., 2002. Recent developments in osmotic dehydration: methods to enhance mass transfer. Trends Food Sci. Technol. 13(2), 48-59.

Rząca M., Witrowa-Rajchert D., Tylewicz U., Dalla Rosa M., 2009. Wymiana masy w procesie osmotycznego odwadniania owoców kiwi [Mass exchange in osmotic dehydration process of kiwi fruits]. Żywn. Nauka Technol. Jakość 6(67), 140-149.

Santacruz-Vazquez C., Santacruz-Vazquez V., JaramilloFlores M.E., Chanona-Perez J., Welti-Chanes J., Gutiérrez-López G.F., 2008. Application of osmotic dehydration processes to produce apple slices enriched with $\beta$-carotene. Drying Technol. 26(10), 1265-1271.

Saurel R., Raoult-Wack A.L., Rios G., Guilbert S., 1994. Mass transfer phenomena during osmotic dehydration of apple I. Fresh plant tissue. Int. J. Food Sci. Technol. 29(5), 531-542.

Sereno A.M., Moreira R., Martinez E., 2001. Mass transfer coefficients during osmotic dehydration of apple in single and combined aqueous solutions of sugar and salt. J. Food Eng. 47(1), 43-49.

Shamaei S., Emam-Djomeh Z., Moini S., 2011. Ultrasoundassisted osmotic dehydration of cranberries: effect of finish drying methods and ultrasonic frequency ontextural properties. J. Text. Stud. 43, 133-141.

Simal S., Benedito J., Sánchez E.S., Rosselló C., 1998. Use of ultrasound to increase mass transport rates during osmotic dehydration. J. Food Eng. 36(3), 323-336.

Sopanangkul A., Ledward D.A., Niranjan K., 2002. Mass transfer during sucrose infusion into potatoes under high pressure. J. Food Sci. 67 (6), 2217-2220.

Tapia M.S., López-Malo A., Consuegra R., Corte P., WeltiChanes J., 1999. Minimally processed papaya by vacuum osmotic dehydration (VOD) techniques/papaya mínimamente procesada mediante técnicas de deshidratación osmótica al vacío (VOD). Food Sci. Technol. Int. 5(1), 41-49.

Taiwo K.A., Eshtiaghi M.N., Ade-Omowaye B.I., Knorr D., 2003 a. Osmotic dehydration of strawberry halves: influence of osmotic agents and pretreatment methods on mass transfer and product characteristics. Int. J. Food Sci. Technol. 38(6), 693-707.

Taiwo K.A., Angersbach A., Knorr D., 2003 b. Effects of pulsed electric field on quality factors and mass transfer during osmotic dehydration of apples. J. Food Process Eng. 26(1), 31-48.

Torreggiani D., 1993. Osmotic dehydration in fruit and vegetable processing. Food Res. Int. 26(1), 59-68. 
Warczok J., Ferrando M., López F., Pihlajamäki A., Güell C., 2007. Reconcentration of spent solutions from osmotic dehydration using direct osmosis in two configurations. J. Food Eng. 80(1), 317-326.

Wiktor A., Witrowa-Rajchert D., 2012. Zastosowanie pulsacyjnego pola elektrycznego do wspomagania procesów usuwania wody z tkanek roślinnych [Applying pulsed electric field to enhance plant tissue dehydration process]. Żywn. Nauka Techn. Jakość 19(2), 22-32 [in Polish].

Wiktor A., Śledź M., Nowacka M., Chudoba T., Witrowa-Rajchert D., 2014. Pulsed electric field pretreatment for osmotic dehydration of apple tissue: experimental and mathematical modeling studies. Drying Techn. 32(4), 408-417.

Viana A.D., Corrêa J.L., Justus A., 2013. Optimisation of the pulsed vacuum osmotic dehydration of cladodes of fodder palm. Int. J. Food Sci. Techn. 49(3), 726-732.
Verma D., Kaushik N., Rao P.S., 2014. Application of high hydrostatic pressure as a pretreatment for osmotic dehydration of banana slices (Musa cavendishii) finish-dried by dehumidified air drying. Food Bioprocess Techn. 7, 1281-1297.

Xin Y., Zhang M., Adhikari B., 2013. Freezing characteristics and storage stability of broccoli (Brassica oleracea L. var. botrytis L.) under osmodehydrofreezing and ultrasound-assisted osmodehydrofreezing treatments. Food Bioprocess Technol. DOI:10.1007/s11947-013-1231-4.

Yadav A.K., Singh SV., 2012. Osmotic dehydration of fruits and vegetables: a review. J. Food Technol. DOI 10.1007/ s13197-012-0659-2.

\section{METODY ZWIĘKSZAJĄCE SZYBKOŚĆ PRZENOSZENIA MASY PODCZAS ODWADNIANIA OSMOTYCZNEGO ŻYWNOŚCI}

\section{STRESZCZENIE}

Tradycyjne metody utrwalania żywności takie, jak zamrażanie, liofilizacja, suszenie próżniowe, suszenie konwekcyjne często są uzupełniane przez nowe technologie umożliwiające wytwarzanie produktów o wysokiej jakości. Odwadnianie osmotyczne coraz częściej jest wykorzystywane podczas przetwarzania owoców i warzyw. Metoda pozwala na zachowanie dobrych właściwości organoleptycznych i funkcjonalnych gotowego produktu. Uzyskanie pożądanego stopnia odwodnienia bądź wysycenia substancją osmoaktywną materiału wymaga długiego czasu lub stosowania wysokich temperatur. W ostatnich latach poświęcono wiele uwagi technikom mającym na celu zwiększenie wymiany masy pomiędzy odwadnianym materiałem a roztworem hipertonicznym. W pracy zamieszczono przegląd literatury poświęconej metodom usprawniającym przebieg odwadniania osmotycznego, do których należą zastosowanie: ultradźwięków, wysokiego ciśnienia hydrostatycznego, próżniowego odwadniania osmotycznego i pulsacyjnego pola elektrycznego.

Słowa kluczowe: odwadnianie osmotyczne, ultradźwięki, wysokie ciśnienie hydrostatyczne, próżniowe odwadnianie osmotyczne, pulsacyjne pole elektryczne

For citation - Do cytowania

Chwastek A., 2014. Methods to increase the rate of mass transfer during osmotic dehydration of foods. Acta Sci. Pol., Technol. Aliment. 13(4), 341-350. 